\title{
Students' Readiness and Problems in Learning English through Blended Learning Environment
}

\author{
Chuanpit Sriwichai \\ The School of Liberal Arts, The University of Phayao, Thailand. \\ Email:chuanpit.sr@up.ac.th
}

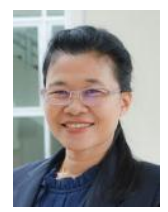

\begin{abstract}
In academic year 2018, the University of Phayao commenced the application of blended learning approach which combines face-to-face class and online learning mode to teaching and learning English as a general education course for the first and second-year students. This study aims to explore students' readiness for learning English course through blended learning environment and investigate problems and challenges that the students faced in their learning. Drawing upon 364 questionnaires with closed and open-ended questions along with focus group interviews with 20 interviewees, the findings revealed that students' readiness for learning English through blended learning was at slightly high level. They tended to be able to learn English through the combination of two different learning modes. They believed that learning English in face-to-face classroom and online learning mode motivated them to be more self-disciplined and responsible for their own learning, and encouraged them to set up their own English learning plans and learning goals. However, the major problems and challenges the students confronted in learning included losing focus on learning in classroom due to considerable class size, limited access of online lessons caused by Learning Management System (LMS) severe crash, difficulty of online interaction with teachers and classmates, lack of experience and skills for digital tools, and time management for two learning modes.
\end{abstract}

Keywords: Students' readiness, Problems in English learning, Challenges in English learning, Blended learning environment, Learning English in blended learning environment, General education English course.

Citation | Chuanpit Sriwichai (2020). Students' Readiness and Problems in Learning English through Blended Learning Environment. Asian Journal of Education and Training, 6(1): 23-34. History:

Received: 23 October 2019

Revised: 26 November 2019

Accepted: 30 December 2019

Published: 3 February 2020

Licensed: This work is licensed under a Creative Commons

Attribution 3.0 License (cc)

Publisher: Asian Online Journal Publishing Group
Acknowledgement: The author would like to express his sincere gratitude and appreciation to the School of Liberal Arts, the University of Phayao for the scholarship. Also, author thankful to all participants of my study for their kind cooperation and attention, and to the lecturers in English Department for their assistance and supports.

Funding: This article was granted by the School of Liberal Arts and the University of Phayao.

Competing Interests: The author declares that there are no conflicts of Competing Interests: The author declares that
interests regarding the publication of this paper.

Transparency: The author confirms that the manuscript is an honest, accurate, and transparent account of the study was reported; that no vital features of the study have been omitted; and that any discrepancies from the study as planned have been explained.

Ethical: This study follows all ethical practices during writing.

\section{Contents}

1. Introduction

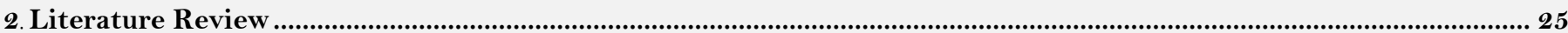

3. Methodology

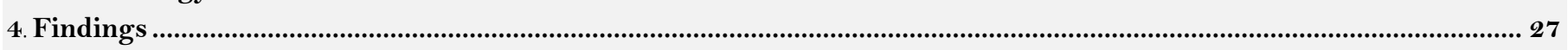

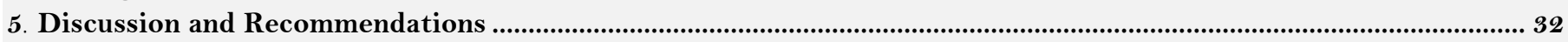

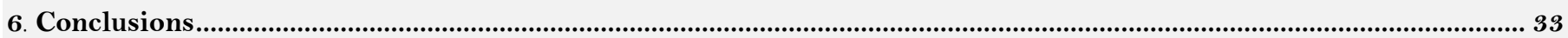

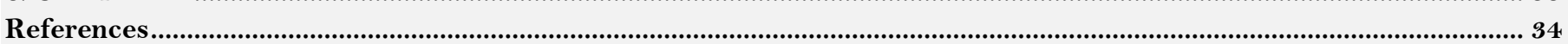




\section{Contribution of this paper to the literature}

This study contributes to the existing literature by exploring students' readiness for learning English course through blended learning environment and investigates problems and challenges that the students faced in their learning.

\section{1 .Introduction}

An advancement of information technology has a considerable impact on significant fields such as education and economy. This rapid growth makes a global community become a digital world. Due to this phenomenon, many countries have created schemes to prepare their citizens for today's modern world, likewise in Thailand. The recent Thai government established a new policy which is called Thailand 4.0 to drive the country toward the digital age. This policy requires educational institutions to reform education system by changing teaching paradigm, curriculum, and teaching methods in order to prepare Thai citizens for digital economy (Royal Thai Embassy, 2015). To follow the policy of the government and to make undergraduate students get ready for a labor market, the University of Phayao launched the project New Seed Graduates (4.0) in academic year 2018. In this project, teaching and learning activities in the General Education courses for first and second-year students are adjusted. One of the General Education courses is "Ready English" which aims to teach students English skills along with developing essential life and career skills such as technology literacy, problem-solving, and collaboration.

Since the academic year 2018, the contents and learning activities of "Ready English" course have been delivered through the university' slearning management system (LMS) and classroom instruction. The students attend in class learning for six times (4 hours each time), so they meet a teacher in face-to-face classroom for 24 out of 60 hours or $40 \%$, and learn on their own pace for 36 out of 60 hours or $60 \%$. According to Allen and Seaman (2013) and Kim (2007) the course that combines face-to-face classroom and online learning modes with the ratio of combination ranging from $30 \%$ to $80 \%$ is considered blended learning course.

Blended learning is a combination of face-to-face classroom instruction and e-learning, or a support of tradition teaching by using internet-based technology such as chat rooms, discussion groups, podcasts, and self-assessment tools (Allan, 2007; Sharma and Barrett, 2007). Banados (2006, cited in Tomlinson and Whittaker (2013) explained that in higher education, blended learning refers to a mix of technology and classroom instruction through a flexible approach that takes advantage from the benefits of online training and assessment and other modes of learning. The purposes of mixing are to make the training program complete and improve learning outcomes and/or reduce costs. Allen and Seaman (2013) also stated that a blended learning course makes use of online and face-to-face delivery modes. Substantial parts of the content can be accessed online, and online discussion is used. Making use of two learning modes is for decreasing the number of face-to-face classroom meetings.

In blended learning environment, the students need to take part in learning both inside and outside the classroom. Moreover, learners in blended learning system are changed from passive learners to be active ones. They become researchers, practitioners, and collaborators because a dynamic and adoptive process of blended learning makes them interact with other learning subsystems including instructor, institution, learning support, content, and technology (Wang et al., 2015). Tang and Chaw (2013) therefore, suggested that students' readiness to learn is a prerequisite for productive implementation of this approach.

In general, readiness for learning refers to the readiness to perform learning activities and the students' existing capacities which related to a specific instructional purpose. Learning goals can be achieved when students' learning is supported by their readiness to handle. Students' readiness can help them to adjust themselves better under difficult circumstances. It is easier for them to understand problems and find solutions. The students' learning readiness correlated with their learning outcomes. The students having more readiness had the greater results of learning, and those who were not ready to do learning tasks faced difficulties in learning or felt frustrated (Winarso, 2016).

In the context of the University of Phayao, the academic year 2019 is the second year when the blended learning approach has been applied to the instruction of General Education English (GEE) courses with the firstyear students who may not be familiar with this learning setting. Hence, realizing the students' readiness for teaching and learning through blended learning environment is significant; yet it is unknown. The present study aims to explore students' readiness through their perspectives on learning English course namely "Ready English" as general education subject through blended learning approach. Also, the problems and challenges students faced in the learning this course were investigated.

The findings of the study contribute to raising teachers and course designers' awareness in designing content and learning activities for blended learning environment which are appropriate for students. Also, policy makers will be given the guideline for what should be focused on in order to promote students' readiness for blended learning setting and improve students' performance in learning English in such environment with the large class size. The objectives of the study were as follows:

1. To explore students' readiness for learning English as general education course through blended learning environment through their self-assessments. 
2. To investigate students' problems and challenges of learning English as general education course through blended learning environment.

\section{Literature Review}

Blended learning is a combination of face-to-face instruction in classroom and technology-mediated learning, or a support of traditional teaching by using internet-based technology such as chat rooms, discussion groups, podcasts, and self-assessment tools (Allan, 2007; Sharma and Barrett, 2007). During the technology-mediated learning mode of this learning environment, students are not required to physically gather in the same classroom, but they can connect digitally through online network. In blended learning course, students could involve in a class taught or directed by a teacher in a face-to-face classroom setting and complete online learning component of the course independently, outside of the classroom through online platform. Online learning experiences may replace classroom instruction and can include interaction with others or learning alone using an independent study. The different learning experiences are complementing each other, and managed to process in parallel (Cleveland-Innes and Wilton, 2018). In short, there are two main delivery modes of learning in the blended learning approach: face-toface classroom learning and online-based learning experience. Hence, blended learning can refer to an incorporation of online learning tools and activities into face-to-face classroom instruction.

Wang et al. (2015) posited that blended learning system consist of six interconnected components. They are teacher, learner, institution, content, technology and learning support. Each of them is independent, but interdependent at the same time. The teacher act as facilitators, moderators, advisors, and learning guides, not just knowledge source while the students become researchers, practitioners, and collaborators. The institution should provide strategies, policy supports, and necessary infrastructures to facilitate teaching and learning in blended setting. The content for blended learning should promote both collaborative and individual learning. The complexity of technology and challenges caused by it should be realized. In addition, the learning support including academic support and technical supports should assist students to develop effective learning strategies such as collaborative work and time management skills. The supports should satisfy students' needs, created by the teacher's knowledge and skills, and advocated by the institution. From abovementioned, when employing blended learning approach, the policy makers should consider all possible factors having impact on students' learning.

Learning readiness is considered the preparation for performing learning activities. Besides, learning readiness is the level of students' exiting capacities related to teaching purposes. Students' readiness is crucial for successful learning in any conditions. The students' learning readiness is correlated with their learning outcomes. The students having more readiness had the greater results of learning, and those who were not ready to do learning tasks faced difficulties in learning or felt frustrated (Winarso, 2016).

In blended learning environment, Tang and Chaw (2013) suggested that students' readiness can be investigated through their viewpoints on six aspects of learning including classroom learning, online learning, online interaction, technology, learning flexibility, and study management. First, classroom learning can create real and meaningful interaction between students and teachers which online learning mode cannot offer. Second, online learning mode, students can spend more time thinking about responses and expressing their ideas or opinions better. This aspect can satisfy introverted learners who may feel uncomfortable with expressing their thoughts in class. The next dimension is online interaction. Blended learning setting should provide opportunities for interaction and discussion which are essential for learning process. Asynchronous web-based tools such as online discussion board can be used to carry out online interaction. Another aspect is concerning technology used in blended learning setting. Information technology is a key element of this approach. High accessibility of and great familiarity with digital tools among students are inevitable for fruitful implementation of blended learning. For learning flexibility, blended learning makes students' learning become flexible and convenient in terms of place and time. They should be able to access course materials on online platforms every time and everywhere when they need. Finally, study management is seen as a process of self-regulated learning in which students put efforts into planning, managing, and directing learning activities, and sharing responsibility with their teachers. The study management is important because it leads to stronger motivation and better time management for learning online. In blended learning environment, students need to be self-disciplined and self-motivated.

Moreover, according to Osman and Hamzah (2017) readiness in adopting blended learning is related to capability to learn on one own, self-reliance in completing given task, feeling comfortable in utilizing technology in learning, and skills for applying e-learning. Besides, readiness for blended learning correlates to good attitudes toward face-to-face and e-learning, interest in following blended learning, and readiness to encounter challenges of such learning experience.

Based on previous studies, the students with positive opinions on the aspects of online learning, study management, online interaction, and learning flexibility tended to be more ready for blended learning approach whereas the students who had strong desires for face-to-face instruction were less ready for blended learning setting. Nonetheless, using technology in learning was not barrier for students (Tang and Chaw, 2013). Furthermore, Osman and Hamzah (2017) found that the level of students' readiness was high for both face-to-face and online learning. On the other hand, the lowest mean score on the statement of self-learning indicated that the 
students might not be ready to learn on their own paces because they still relied on teachers' guidance. Additionally, Suwannasom and Catane (2016) disclosed that the participants had positive attitudes and motivation in learning English through online activities. They perceived blended language learning was convenient and able to promote self-directed learning. Online learning mode enabled students to take more control and responsibility in learning and practicing language skills. When they confronted problems in learning, they used internet-based resources to self-study the most, and the second most source for consulting was textbook. Therefore, it was suggested that sufficient materials and availability of online resources were vital for blended learning implementation. However, the students needed the teacher's help to enhance their quality of learning and guide them in new learning settings.

\section{Methodology}

\subsection{Population and Samples}

The population of the study was 3,911 students who were first year undergraduates enrolled in the Ready English course which is one of General Education English courses of the University of Phayao in the first semester, academic year 2019. The sample size was calculated using Yamane's formula with a confident level 95\% and an error $5 \%(\mathrm{P}=0.05)$. The formula was shown below

$$
n=\frac{N}{1+N(e)^{2}}
$$

Based on the above formula, this study obtained 364 samples. After the sample size was determined, the samples were classified into cluster based on their schools and subject areas.

\subsection{Instruments}

The six dimensions of readiness for learning stated by Tang and Chaw (2013) and the concept of readiness for adopting blended learning proposed by Osman and Hamzah (2017) were used as a framework to develop the questionnaire. The statements in the instrument were adapted from their studies and categorized into 7 parts: classroom learning, online learning, online interaction, technology, learning flexibility, learning management, and readiness for blended learning. The instrument utilized 4 -Likert scale ( $1=$ strongly disagree, and $4=$ strongly agree) to avoid central tendency bias (Kostoulas, 2013). To provide the participants a better understanding of the questionnaire contents, the items were in Thai. Also, an open-ended question (i.e. What problems did you face in learning English in this course both face-to-face classroom and online learning modes?) was applied to elicit qualitative information of students' problems and challenges in learning English through a blended learning approach. This question was also used in the focus group interview to provide deep insight of the students' problems.

\subsection{Validity and Reliability of the Instruments}

The questionnaire was evaluated by 3 experts using the Index of Item Objective Congruence (IOC). The IOC value was .88 . Then, the questionnaire was tried out with 30 students to verify reliability, and Cronbach's Alpha value was.82.

\subsection{Data Collection}

The data were collected in "Ready English" course in the $1^{\text {st }}$ semester, academic year 2019 at the University of Phayao. The data were collected only once after the ethical approval. The questionnaires were distributed at the beginning of the class, and the data collection lasted about 20-30 minutes. After that, the focus group interviews were undertaken with 20 students ( 5 students in each group).

\subsection{Ethical Approval}

Prior to conducting the study, the researcher applied for Ethical Considerations Involved in Research on Human Subjects to University of Phayao Human Ethics Committee, and the certificate number of approval is 2/033/62. Before collecting data, the population was informed the research objectives and asked for their voluntary participation. After that, the samples who voluntarily took part in the study signed their signatures in the consent form.

The questionnaires were kept in a safe place, and the data were recorded in a computer which the password to login was necessary. The data will be kept for 3 years. The hard copy of the data will be eliminated using document shredder, and the soft files of the data will be deleted.

\subsection{Data Analysis}

Frequency and percentage were used to figure out the students' demographic data from part one of the questionnaire. Mean and standard deviation were employed to examine students' readiness in 7 aspects. The criteria used to interpret mean values (Srisa-ard, 2010) were as follows:

$$
\begin{array}{ll}
3.76-4.00 & =\text { students have high level of readiness } \\
2.76-3.75 & =\text { students have slightly high level of readiness }
\end{array}
$$


$1.76-2.75=$ students have slightly low level of readiness

$1.00-1.75=$ students have low level of readiness

The qualitative data of students' learning problems and challenges from open-ended question and the focus group interviews were examined using thematic analysis and coding method. The participants' responses were translated from Thai to English and coded line-by-line. Then the emergent codes were categorized to 7 key themes based on the main parts in the questionnaire.

\section{Findings}

\subsection{Demographic Information of the Samples}

The samples' demographic data of schools and subject areas were presented in the following table.

Table-1. Samples'demographic data classified by schools and subject areas.

\begin{tabular}{|c|c|c|c|c|}
\hline No. & Schools & Subject Areas & Number & Percentage \\
\hline \multirow[t]{6}{*}{1.} & \multicolumn{2}{|c|}{ Agriculture and Natural Resources } & 28 & 7.60 \\
\hline & & Animal Sciences & 7 & 1.90 \\
\hline & & Agriculture & 7 & 1.90 \\
\hline & & Food Safety & 4 & 1.10 \\
\hline & & Fisheries & 4 & 1.10 \\
\hline & & Food Science and Technology & 6 & 1.60 \\
\hline \multirow[t]{3}{*}{2.} & \multicolumn{2}{|c|}{ Allied Health Sciences } & 16 & 4.30 \\
\hline & & Medical Technology & 10 & 2.70 \\
\hline & & Physical Therapy & 6 & 1.60 \\
\hline \multirow[t]{4}{*}{3.} & \multicolumn{2}{|c|}{ Education } & 34 & 9.40 \\
\hline & & Education - English & 9 & 2.50 \\
\hline & & Education - Thai & 20 & 5.50 \\
\hline & & Education -Social Development & 5 & 1.40 \\
\hline \multirow[t]{5}{*}{4.} & \multicolumn{2}{|c|}{ Engineering } & 20 & 5.40 \\
\hline & & Civil Engineering & 9 & 2.50 \\
\hline & & Electrical Engineering & 2 & 0.50 \\
\hline & & Industrial Engineering & 3 & 0.80 \\
\hline & & Mechanical Engineering & 6 & 1.60 \\
\hline \multirow[t]{9}{*}{5.} & \multicolumn{2}{|c|}{ Information and Communication Technology } & 42 & 11.4 \\
\hline & & Business Computer & 7 & 1.90 \\
\hline & & Computer Engineering & 7 & 1.90 \\
\hline & & Computer Graphics & 11 & 3.00 \\
\hline & & Computer Science & 6 & 1.60 \\
\hline & & Engineering Software & 4 & 1.10 \\
\hline & & Geographic Information Science & 2 & 0.50 \\
\hline & & Information Technology & 4 & 1.10 \\
\hline & & Information Technology - English & 1 & 0.30 \\
\hline \multirow[t]{5}{*}{6.} & \multicolumn{2}{|l|}{ Law } & 21 & 5.80 \\
\hline & & Law & 5 & 1.40 \\
\hline & & Law - Information Technology & 6 & 1.60 \\
\hline & & Law - Accounting & 5 & 1.40 \\
\hline & & Law - English & 5 & 1.40 \\
\hline \multirow[t]{8}{*}{7.} & \multicolumn{2}{|c|}{ Liberal Arts } & 41 & 11.30 \\
\hline & & Chinese & 5 & 1.40 \\
\hline & & English & 10 & 2.70 \\
\hline & & French & 5 & 1.40 \\
\hline & & Japanese & 5 & 1.40 \\
\hline & & Thai & 5 & 1.40 \\
\hline & & Chinese - English & 5 & 1.40 \\
\hline & & French - English & 6 & 1.60 \\
\hline \multirow[t]{4}{*}{8.} & \multicolumn{2}{|l|}{ Medicine } & 16 & 4.4 \\
\hline & & Community Health & 7 & 1.90 \\
\hline & & Environmental Health & 5 & 1.40 \\
\hline & & Occupational Health and Safety & 4 & 1.10 \\
\hline \multirow[t]{4}{*}{9.} & \multicolumn{2}{|c|}{ Medical Sciences } & 28 & 7.7 \\
\hline & & Biochemistry & 7 & 1.90 \\
\hline & & Microbiology & 9 & 2.50 \\
\hline & & Nutrition & 12 & 3.30 \\
\hline
\end{tabular}




\begin{tabular}{|c|c|c|c|c|}
\hline No. & Schools & Subject Areas & Number & Percentage \\
\hline \multirow[t]{6}{*}{10.} & \multicolumn{2}{|c|}{ Management and Information Sciences } & 52 & 14.3 \\
\hline & & Accountancy & 24 & 6.60 \\
\hline & & Communication Management & 7 & 1.90 \\
\hline & & Economics & 5 & 1.40 \\
\hline & & New Media Communication & 5 & 1.40 \\
\hline & & Tourism & 11 & 3.00 \\
\hline \multirow[t]{2}{*}{11.} & \multicolumn{2}{|l|}{ Nursing } & 10 & 2.70 \\
\hline & & Nursing Science & 10 & 2.70 \\
\hline \multirow[t]{2}{*}{12.} & \multicolumn{2}{|c|}{ Pharmaceutical Sciences } & 10 & 2.70 \\
\hline & & Pharmaceutical Sciences & 10 & 2.70 \\
\hline \multirow[t]{7}{*}{13.} & \multicolumn{2}{|l|}{ Science } & 28 & 7.70 \\
\hline & & Biology & 3 & 0.80 \\
\hline & & Chemical Industry and Materials Technology & 1 & 0.30 \\
\hline & & Chemistry & 9 & 2.50 \\
\hline & & Physics & 3 & 0.80 \\
\hline & & Science and Technology in Sports & 9 & 2.50 \\
\hline & & Statistics & 3 & 0.80 \\
\hline \multirow[t]{2}{*}{14.} & \multicolumn{2}{|c|}{ Energy and Environment } & 1 & 0.30 \\
\hline & & Environmental Engineering & 1 & 0.30 \\
\hline \multirow[t]{5}{*}{15.} & \multicolumn{2}{|c|}{ Political and Social Sciences } & 17 & 4.60 \\
\hline & & Political Science & 10 & 2.70 \\
\hline & & Public Administration & 3 & 0.80 \\
\hline & & Public Innovation Management & 1 & 0.30 \\
\hline & & Social Development & 3 & 0.80 \\
\hline \multicolumn{3}{|c|}{ Total } & 364 & 100.00 \\
\hline
\end{tabular}

Table 1 demonstrated the demographic information of schools and subject areas of the samples. There were 364 participants from 15 schools consisting of 58 subject areas. Most participants were from the School of Management and Information Sciences (52 students $=(\% 3.14$ including five subject areas. The second most was the students from the School of Information and Communication Technology with eight subject areas (42 students = (\% 4.11, followed by the School of Liberal Arts comprising seven subject areas (41 students $=(\% 3.11$, and the College of Education with three subject areas (34 students = . $\%$ 4.9The participants were from the School of Energy and Environment the least $(1$ student $=. .(\% 30$ The second least was the samples from the School of Nursing and the School of Pharmaceutical Sciences (10 students $=.(\% 7.2$

\subsection{Students Readiness for Learning English as General Education Course through Blended Learning Environment through their Self-Assessment}

The results of the students' readiness in 7 aspects based on the questionnaire were presented as follows:

\begin{tabular}{l|l|l|c|c}
\multicolumn{1}{c}{ Table-2. Classroom learning. } \\
\hline No. & Items & $\bar{\chi}$ & SD & Meaning \\
\hline 1 & Classroom Learning & & & \\
\hline $\begin{array}{l}\text { Face-to-face English classroom activities help prepare me to learn on my own } \\
\text { pace through online learning. }\end{array}$ & 3.13 & .50 & Slightly high \\
\hline 2 & $\begin{array}{l}\text { Face-to-face English classroom activities help me to generate ideas to do } \\
\text { course assignment. }\end{array}$ & 3.00 & .51 & Slightly high \\
\hline 3 & $\begin{array}{l}\text { In face-to-face English classroom, I have a chance to get supports or } \\
\text { feedbacks from my teacher and peers immediately. }\end{array}$ & 2.98 & .59 & Slightly high \\
\hline 4 & I learn English better through teacher-directed classroom-based activities. & 2.95 & .61 & Slightly high \\
\hline 5 & $\begin{array}{l}\text { I learn English better when I collaborate with others in face-to-face } \\
\text { classroom. }\end{array}$ & 2.98 & .64 & Slightly high \\
\hline 6 & $\begin{array}{l}\text { I believe face-to-face English classroom learning is more effective than English } \\
\text { online learning. }\end{array}$ & 3.12 & .68 & Slightly high \\
\hline 7 & I am bored when learning English in this course in face-to-face classroom. & 2.61 & .70 & Slightly low \\
\hline & \multicolumn{1}{|l}{ Slightly high } \\
\hline
\end{tabular}

Table 2 presented students' readiness for classroom activities. The overall mean scores were in slightly high level $(\bar{\chi}=2.94, \mathrm{SD}=.31)$. Six out of seven items gained slightly high mean scores and only one item was rated in slightly low mean. The highest mean score was No. 1 'Face-to-face English classroom activities help prepare me to learn on my own pace through online learning' $(\bar{\chi}=3.13, \mathrm{SD}=.50$ ), followed by No. 6 'I believe face-to-face English 
classroom learning is more effective than English online learning' $(\bar{\chi}=3.12, \mathrm{SD}=.68$ ). The lowest mean score was found in No. 7 'I am bored when learning English in this course in face-to-face classroom' $(\bar{\chi}=2.61, \mathrm{SD}=.70$ ).

Table-3. Online learning

\begin{tabular}{l|l|c|c|c}
\hline $\mathbf{N o .}$ & Items & $\bar{\chi}$ & SD & Meaning \\
\hline 1 & Online Learning & & & \\
\hline 2 & Learning English online in this course is interesting and convenient. & 3.02 & .55 & Slightly high \\
\hline 3 & $\begin{array}{l}\text { I feel comfortable with self-directed learning when I learn English online in this } \\
\text { course. }\end{array}$ & 2.94 & .59 & Slightly high \\
\hline $\begin{array}{l}\text { I like learning English online in this course because it enables me to access } \\
\text { instructional content easier. }\end{array}$ & 2.88 & .67 & Slightly high \\
\hline 5 & $\begin{array}{l}\text { I would like learning time in the classroom of this English course to be reduced. } \\
\text { I would like to have online class for this English course rather than in the } \\
\text { classroom. }\end{array}$ & 2.83 & .76 & Slightly high \\
\hline 6 & I am bored when learning English online. & 2.60 & .79 & Slightly low \\
\hline & \multicolumn{2}{|l}{ Slightly low } \\
\hline
\end{tabular}

Table 3 demonstrated readiness of the students for online learning. The total mean score was slightly high $(\bar{\chi}=$ 2.79, $\mathrm{SD}=.39$ ). There were four items obtained slightly high mean while two items had slightly low mean. The item having the highest mean was No.1 'Learning English online in this course is interesting and convenient' $(\bar{\chi}=3.02$, $\mathrm{SD}=.55$ ) whereas No. 6 'I am bored when learning English online' gained the lowest mean $(\bar{\chi}=2.60, \mathrm{SD}=.79$ ).

Table-4. Online interaction.

\begin{tabular}{|c|c|c|c|c|}
\hline No. & Items & $\bar{\chi}$ & SD & Meaning \\
\hline & Online Interaction & & & \\
\hline 1 & I feel isolated when I learn English online. & 2.60 & .81 & Slightly low \\
\hline 2 & I would like to interact with my teacher when I learn English online. & 2.97 & .60 & Slightly high \\
\hline 3 & I would like to interact with my classmates when I learn English online. & 2.99 & .61 & Slightly high \\
\hline 4 & $\begin{array}{l}\text { When I learn English online, I can communicate with teacher or } \\
\text { classmates online easily. }\end{array}$ & 2.82 & .68 & Slightly high \\
\hline \multirow[t]{2}{*}{5} & $\begin{array}{l}\text { I can collaborate well with my team in doing assignments of this English } \\
\text { course. }\end{array}$ & 2.99 & .62 & Slightly high \\
\hline & & 2.83 & .42 & Slightly high \\
\hline
\end{tabular}

Table 4 showed the mean rating of students' self-assessments on online interaction in English blended learning setting. All items were in slightly high scales, except No. 1 that was rated on a slightly low level. Overall mean score of this part was in slightly high level at 2.83 ( $\mathrm{SD}=42$ ). The items that got the greatest mean were No. 3 'I would like to interact with my classmates when I learn English online' $\bar{\chi}=2.99, \mathrm{SD}=.61$ ) and No. 5 'I can collaborate well with my team in doing assignments of this English course' $(\bar{\chi}=2.99, \mathrm{SD}=.62$ ). The lowest mean rating was item 1 'I feel isolated when I learn English online' $\bar{\chi}=2.60, \mathrm{SD}=.81$ ).

Table-5.Technology.

\begin{tabular}{l|l|c|c|c}
\hline No. & Items & $\bar{\chi}$ & SD & Meaning \\
\hline 1 & Technology & & & \\
\hline 2 & $\begin{array}{l}\text { I think online learning platform (www.lms.up.ac.th) used in } \\
\text { English teaching and learning of this course is easy to use. }\end{array}$ & 3.04 & .59 & Slightly high \\
\hline $\begin{array}{l}\text { I believe online learning platform (www.lms.up.ac.th) used in } \\
\text { teaching and learning of this course is useful for my English } \\
\text { learning. }\end{array}$ & $\begin{array}{l}\text { I think this online learning platform should be used in teaching } \\
\text { and learning other English courses. }\end{array}$ & 3.04 & .55 & Slightly high \\
\hline & \multicolumn{1}{|c|}{3.07} & .39 & Slightly high high \\
\hline
\end{tabular}

According to Table 5 the mean score of the students' perception on online-based technology used in this course was in a slightly high level $\bar{\chi}=3.07, \mathrm{SD}=.39$ ). Item 2 'I believe online learning platform (www.lms.up.ac.th) used in teaching and learning of this course is useful for my English learning' $\bar{\chi}=3.12, \mathrm{SD}=.53$ ) was rated highest whereas item 1 'I think online learning platform (www.lms.up.ac.th) used in English teaching and learning of this course is easy to use' $(\bar{\chi}=3.04, \mathrm{SD}=.59)$ and item 3 'I think this online learning platform should be used in teaching and learning other English courses' $\bar{\chi}=3.04, \mathrm{SD}=.55$ ) obtained lower means. 
Table-6. Learning flexibility.

\begin{tabular}{|c|c|c|c|c|}
\hline No. & Items & $\bar{\chi}$ & SD & Meaning \\
\hline & Learning Flexibility & & & \\
\hline 1 & $\begin{array}{l}\text { I would like to access the teaching materials and the English lessons } \\
\text { without limits of time and place. }\end{array}$ & 3.32 & .60 & Slightly high \\
\hline 2 & $\begin{array}{l}\text { I would like to decide where and when I want to study the English } \\
\text { lessons. }\end{array}$ & 3.10 & .67 & Slightly high \\
\hline \multirow[t]{2}{*}{3} & I like to study English lessons of this course at my own pace. & 2.81 & .70 & Slightly high \\
\hline & & 3.08 & .49 & Slightly high \\
\hline
\end{tabular}

Table 6 described the students' self-assessment in term of learning flexibility. All three items were rated slightly high, and the overall mean was 3.08 ( $\mathrm{SD}=.49$ ). The highest-rated item was No. 1 'I would like to access the teaching materials and the English lessons without limits of time and place' $(\bar{\chi}=3.32, \mathrm{SD}=.60$ ), and the lowest-rated one was No. 3 'I like to study English lessons of this course at my own pace' $\bar{\chi}=2.81, \mathrm{SD}=.70$ ).

Table-7. Learning management.

\begin{tabular}{|c|c|c|c|c|}
\hline No. & Items & $\bar{\chi}$ & SD & Meaning \\
\hline & Learning Management & & & \\
\hline 1 & $\begin{array}{l}\text { Learning English in both face-to-face classroom and online learning mode } \\
\text { motivate me to be more self-disciplined and responsible for my learning } \\
\text { English. }\end{array}$ & 3.12 & .53 & Slightly high \\
\hline 2 & $\begin{array}{l}\text { Learning English in both face-to-face classroom and online learning mode } \\
\text { encourage me to set up my own English learning plans and goals. }\end{array}$ & 3.13 & .52 & Slightly high \\
\hline 3 & I can organize my time efficiently in learning English. & 2.96 & .59 & Slightly high \\
\hline \multirow[t]{2}{*}{4} & $\begin{array}{l}\text { When I have problems in learning, I can find the ways to solve them (e.g. } \\
\text { asking for assistance from others, or finding information from the internet. }\end{array}$ & 3.21 & .52 & Slightly high \\
\hline & & 3.11 & .40 & Slightly high \\
\hline
\end{tabular}

Based on Table 7 the mean rating of learning management was in slightly high level at $3.11(\mathrm{SD}=.40)$. Item 4 'When I have problems in learning, I can find the ways to solve them (e.g. asking for assistance from others, or finding information from the internet' $\bar{\chi}=3.21, \mathrm{SD}=.52$ ) was rated highest while item 3 'I can organize my time efficiently in learning English' $\bar{\chi}=2.96, \mathrm{SD}=.59$ ) was rated lowest.

Table-8. Readiness for blended learning.

\begin{tabular}{|c|c|c|c|c|}
\hline No. & Items & $\bar{\chi}$ & SD & Meaning \\
\hline & Readiness for Blended Learning & & & \\
\hline 1 & $\begin{array}{l}\text { I want to learn English in blended learning environment which } \\
\text { combines face-to-face and online learning rather than learning in face- } \\
\text { to-face classroom only. }\end{array}$ & 3.19 & .68 & Slightly high \\
\hline 2 & $\begin{array}{l}\text { I want to learn English in blended learning environment which } \\
\text { combines face-to-face and online learning rather than learning online } \\
\text { fully. }\end{array}$ & 3.14 & .65 & Slightly high \\
\hline 3 & $\begin{array}{l}\text { I am ready to face challenges in learning English in blended learning } \\
\text { environment (combining face-to-face classroom and online learning). }\end{array}$ & 3.07 & .65 & Slightly high \\
\hline \multirow[t]{2}{*}{4} & $\begin{array}{l}\text { If I have an opportunity, I want to register in an English course that } \\
\text { adopt blended learning approach (combining face-to-face classroom and } \\
\text { online learning). }\end{array}$ & 2.99 & .63 & Slightly high \\
\hline & & 3.10 & .52 & Slightly high \\
\hline
\end{tabular}

Table 8 exhibited the results of students' readiness for blended learning analysis. All four items of this dimension got slightly high mean score, and total mean was $(\bar{\chi}=3.10, \mathrm{SD}=.52$ ). While item 1 'I want to learn English in blended learning environment which combines face-to-face and online learning rather than learning in face-to-face classroom only' was rated highest $(\bar{\chi}=3.19, \mathrm{SD}=.68$ ), item 4 ' 'If I have an opportunity, I want to register in an English course that adopt blended learning approach (combining face-to-face classroom and online learning' was rated lowest $(\bar{\chi}=2.99, \mathrm{SD}=.63)$.

\subsection{Students Problems and Challenges in Learning English as General Education Course through Blended Learning Environment}

The findings of students' problems and challenges in learning English as general education course through blended learning environment were elicited from 107 responses of the open-ended question in the questionnaire and 20 interviewees of the focus group interviews. The data were classified into seven main themes corresponding to seven aspects of students' readiness in the questionnaire and described as follows: 


\subsubsection{Problems and Challenges Related to Classroom Learning}

The main challenge of classroom learning was the class size. It was stated that the large number of students in one class was their obstacle to focus on the study because high noise level from students' chatting distracted their attention, and it was difficult for them to interact with the teacher when they have questions or need explanation. It was noted:

"There are too many students, and they talk loudly while the teacher is teaching, so I cannot focus on learning."

"The class is very large. It is inconvenient for me to ask the teacher or teacher assistants when I have questions, so I cannot understand contents clearly."

This was also found in the interview data. The interviewees said that the considerable class size caused problems for their learning. One of them reported:

"There are more than 200 students in my class. It is difficult to communicate with teacher and teacher assistant. When the teacher teaches or give information about course assignments I cannot hear because my classmates talk loudly."

\subsubsection{Problems and Challenges Related to Online Learning}

Regarding the second main theme, the samples thought learning online was more complicated than learning in classroom and online materials was not sufficient and was difficult to understand. It was exposed:

"The online content are not enough, and online lessons are not interesting for me. The lessons should be more attractive and the content should be added"

"Online learning is much more complicated than classroom learning."

In addition, it was reported in the interview that online learning is boring because the students do not understand online content. It was disclosed:

"I cannot understand the lesson clearly when I learn online, and I cannot ask the teacher, so it is not interesting for me."

\subsubsection{Problems and Challenges Related to Online Interaction}

For main theme three, the respondents noted in the questionnaire that they could not contact or interact with the teachers, teacher assistants, or their classmates instantly while they were studying online. They stated:

"When I do not understand online learning contents, I cannot ask teacher for more explanation immediately."

"I do not understand online learning content and I cannot ask for helps from others."

Likewise, the data from the interview revealed that it was difficult for the students to communicate with the teachers. Some teachers allowed them to contact him or her by using e-mail; however, the reply was somewhat late. It was reported:

"When I have questions about the lessons, I have sent my teacher e-mail, but I take a few days for reply. Sometimes I need urgent help."

\subsubsection{Problems and Challenges Related to using Technology}

Lack of experience and skills for learning English through online-based technology used in blended learning contributed to the students' challenges. Some respondents mentioned:

"I have not studied online before, so the steps to access online learning platform is confusing and complicated for me"

"I do not have enough skills for using online learning platform, so I feel discouraged to learn online."

\subsubsection{Problems and Challenges Related to Learning Flexibility}

Both questionnaire respondents and interviewees mentioned a limited access to online materials due to slow internet connection was one problem of their learning. They were unable to access online lesson and material based on their own desire. They revealed:

"Online material is unable to access when I want, even before an exam"

"The university LMS often goes down, so I cannot access the lesson when I want."

\subsubsection{Problems and Challenges Related to Students Learning Management}

Time management for learning in two different modes of blended learning was perceived as the challenge English learning for the students. Some of them mentioned that they did not learn online and preview textbook before attending face-to-face classroom. It was disclosed:

"I have problems in managing my time for both in-class and online learning"

"I sometimes did not study online content and do exercise before coming to the class, so I do not understand the contents clearly. I think some students are not self-disciplined for learning online" 
Similarly, the interviewees had problem in allocating time for learning English in two modes of learning because they had to be responsible for tasks and activities of other courses. One interviewee said:

"I rarely go online for learning English because I have to do homework and assignments of other subjects."

\subsubsection{Problems and Challenges Related to Readiness for Blended Learning}

Some students revealed that they lacked motivation to learn English in blended learning condition. They felt it was difficult for them to learn inside and outside classroom. Also, inadequate essential knowledge of English vocabulary and grammar structures was mentioned as one of the challenges to learn on their own through online learning mode. It was noted:

"Sometimes I feel lazy to learn online and wake up early to attend the class."

"I have limited range of vocabulary and knowledge of grammar, so I cannot understand content clearly."

Furthermore, it was found from the focus group interview that classroom learning was considered more attractive and productive for them. The students believed face-to-face class meeting was a great chance for building good relationship between teacher and students, and they could gain more knowledge in classroom. One of them said:

"I think in classroom, the teacher and students can know each other and have good relationship. I like learning English in classroom because I pay attention to the teacher's instruction, so I gain more knowledge."

\section{Discussion and Recommendations}

The overall mean score of classroom learning mode was higher than online learning. According to the slightly high means of the items in classroom learning part, the possibility that the respondents believed face-to-face classroom learning was more effective than English online learning, and they could learn English better through in-class learning. This meant students still perceived face-to-face learning essential for them, and they want to learn through the setting in which there were teachers and peers with them. However, the main problem mentioned by both the questionnaire respondents and the interviewees was the considerable class size. Because of a large number of students in the class, the high level of noise was inevitable. This contributed to the lack of students' focus on study. Students also perceived that in the large class, it was not easy for interacting with teacher when they need help. Regarding these factors, the students could not completely comprehend learning contents and enjoy their classes. These findings were supported by Bahanshal (2013) who found that the enormous number of students in one class was responsible for some problems that affected both teachers and the students. Some commonly problems included no communication, lack of individual attention, uncontrollable class, and ineffectiveness of learning activities.

Second, the total mean of the online learning part was the lowest. The slightly low mean of item 5 of online learning aspect reflected that if students were required to choose one of learning modes between learning in classroom and online learning, they would prefer the former to the latter. It could be assumed that the respondents might not feel comfortable and not be ready for a full online course in which they are required to perform learning process by themselves. This echoed by Osman and Hamzah (2017) who stated that the lowest mean score of the item on self-learning could reflect students' low readiness to learn on their own since they still relied on the teacher. On the other hand, the qualitative data analysis unveiled that online lessons were uninteresting for some students because the lessons were not engaging. For certain students, this part was not interesting because of the difficulty of communication with the teachers and the complexity of online platform access.

The results of the online learning part were in line with those of the online interaction section that the mean score was the second lowest. Three highest-rated items (No. 2, 3, and 5) of the online interaction dimension showed that the students desired to interact with their teachers and classmates, and collaboratively work with their teams when they learned online. Nevertheless, the questionnaire's respondents and the interviewees reported that they could not contact with the teachers or peers when they needed immediate supports or helps in learning English online, so they could not comprehend the lessons and felt bored. It could be seen from this notable finding the interaction and discussion were necessary and inevitable for blended learning process. It was in alignment with the previous study that suggested the novice of blended learning may get lost in the learning process in which they were required to be more independent through language learning using technology. They, hence, needed teachers' guidance and peers' advocacy when they learned digital lessons (Suwannasom and Catane, 2016). Blended learning environment should offer students a plenty of chances to interact and discuss with facilitators and classmates using web-based tools such as discussion board (Tang and Chaw, 2013). The university's LMS used in this blended English course offered the discussion forum and dashboard for communication among teachers and class members, yet it has been unfamiliar to the users.

From the questionnaire analysis, the students expressed great attitudes toward technology or learning management system (LMS) used in this blended English course. They seemed to realize that the digital tool was useful for their English learning. However, the qualitative data online platform access seemed to be complex for 
some students. This may be because the students were not familiar with learning English through online platform because they were first-year students, and they needed more training for access and use of the platform in their learning. This could be seen from responses stating that some students had no experience in learning through online mode. Kenney and Newcombe (2011) explained that for many students it might be their first time for involving in blended learning setting, so it was important to have them get familiar with the online learning tools, online materials available and class schedule. Furthermore, students should be provided technical and learning support in order to ensure they feel comfortable in making use online learning tools such as using discussion forum to discuss their problems or questions related to learning contents and activities. Moreover, Tang and Chaw (2013) suggested that for productive implementation of blended learning, it is necessary to provide students high level of familiarity with and accessibility of online learning tools because using technology was the main characteristic of blended learning.

In learning flexibility section, the highest mean score of item 1 may reflect that students needed to learn without time limitation. Tang and Chaw (2013) posited that when the learners showed positive attitudes towards learning flexibility, they tended to be adaptable to blended learning. However, the responses of the open-ended question and the interview revealed that online lessons were not flexible for students. They could not access knowledge through online platform when they desired to learn because the server of the platform always crashed.

The total mean of the learning management dimension was the second highest of all. Based on the highest-rated items (No.1, 2, and 4), the students believed that learning English in both face-to-face classroom and online learning mode motivated them to be more self-disciplined and responsible for their own learning, and encouraged them to set up their own English learning plans and learning goals. These findings are promising because students were assumed to have willingness to take responsibility for their own learning, and be adept at planning learning time to accomplish their learning goals which is necessary for achieving learning goals. On the other hand, it was stated that the big challenge for students was management of time. It seemed to be difficult for them to allocate time for learning online along with preparing themselves for learning in classroom. According to Raadt and Dekeyser (2009) time management was a significant element contributing to success in blended learning in tertiary educational level. However, many undergraduate students encountered the difficulty in managing time in blended learning setting in which they were required to learn online along with face-to-face learning (Vaughan, 2007).

Finally, the overall mean of the readiness for blended learning part was the highest of all aspects. Also, the mean scores of the items 1 and 2 of this part concerning face-to-face learning and online learning mentioned that they want to learn English in blended learning environment which combines face-to-face and online learning rather than learning in only face-to-face or online learning. Based on these findings, the students were likely to be ready to learn English as general education course through blended learning setting. However, certain respondents and interviewees recounted that they lacked motivation to learn in two different modes of learning. Also, insufficient prior knowledge of English vocabulary and grammar could be the barrier for students' self-study in online learning mode. To prepare students for independently learning on their own through online learning part, face-to-face classroom instruction should give the students essential knowledge they can apply to web-based learning.

The findings of the present study did not only reflect the students' readiness for learning English as general education course through blended learning environment, but also reflected the readiness of teachers, learning management policy, and supportive learning system provided by the university. It was found that an achievement of successful implementation of blended learning is related to various elements. Prior to implementing blended learning, the teachers should be trained about the concept of this method together with how to incorporate online learning mode to face-to-face classroom. Also, they should be trained to handle with the large class size. Similarly, students should be trained how to learn online, and manage their time for both learning modes, provided supports when they face problems in learning. The interaction between teacher and students during the implementation of blended learning approach is very important, so online and offline communication tools should be provided, especially when the class size is very large. In case digital discussion tools have been provided, teachers and students should be informed and demonstrated how to use them to give and seek advice or help. Also, technologymediated activities such as live online tutoring and discussion should be incorporated in order to enhance students learning engagement.

For further research, the readiness of other sectors in blended learning system such as the readiness of teacher, institution, or technology and learning supports should be investigated in order to provide well-rounded understanding of blended learning implementation.

\section{Conclusions}

The results of the quantitative data analysis showed that the total mean score of each aspect in the questionnaire was in a slightly high level. It meant students were somewhat ready for blended learning. However, the responses from the open-ended question and the focus group interviews disclosed some problems and challenges of the students that needed to be taken into consideration when implementing blended learning setting. These included losing attention to learning in classroom due to large class size, limited accessibility of online lessons because of LMS severe crash, difficulty of online interaction with teachers and peers, lack of experience and skills for using LMS, and time management for two learning modes. 


\section{References}

Allan, B., 2007. Blended learning: Tools for teaching and training. London: Facet Publishing.

Allen, E. and J. Seaman, 2013. Changing course: Ten years of tracking online education in the United States. Available from https://files.eric.ed.gov/fulltext/ED541571.pdf.

Bahanshal, D.A., 2013. The effect of large classes on English teaching and learning in Saudi secondary schools. English Language Teaching, 6(11): 49-59.

Cleveland-Innes, M. and D. Wilton, 2018. Guide to blended learning. Canada: Common Wealth of Learning.

Kenney, J. and E. Newcombe, 2011 . Adopting a blended learning approach: Challenges encountered and lessons learned in an action research study. Journal of Asynchronous Learning Networks, 15(1): 45-57.Available at: https://doi.org/10.24059/olj.v15i1.182.

Kim, W., 2007. Toward a definition and methodology for blended learning. In J. Fong and F. L. Wang (eds.), The proceedings of workshop on blended learning 2007: 1-8. Available from https://www.academia.edu/1357530/ Blended_Learning_Towards_a_Mix_for _SMEs-Stakeholders_and_their_Priorities.

Kostoulas, A., 2013. Four things you probably didn't know about likert scales. Available from https://achilleaskostoulas.com/2013/09/09/FOUR-THINGS-YOU-PROBABLY-DIDNT-KNOW-ABOUT-LIKERTSCALES/.

Osman, N. and M.I. Hamzah, 2017. Student readiness in learning Arabic Language based on blended learning. International Journal of Applied Linguistics and English Literature, 6(5): 83-89.Available at: https://doi.org/10.7575/aiac.ijalel.v.6n.5p.83.

Raadt, M. and S. Dekeyser, 2009. A simple time-management tool for students' online learning activities. In Same Places, Different Spaces: Proceedings Ascilite Auckland 2009.

Royal Thai Embassy, 2015. Agenda 1: Prepare Thais 4.0 for Thailand becoming a first world nation. Available from http://thaiembdc.org/agenda-1-prepare-thais-4-O-for-thailand-becoming-a-first-world-nation/.

Sharma, P. and B. Barrett, 2007. Blended learning: Using technology in and beyond the language classroom. New York: Macmillan.

Srisa-ard, B., 2010. Introduction to researching. 8th Edn., Bangkok: Suweeriyasarn.

Suwannasom, T. and N.G. Catane, 2016. Exploring University students' attitudes and strategies in a blended English Language learning environment. KKU International Journal of Humanities and Social Sciences, 6(1): 10-31.

Tang, C. and L. Chaw, 2013. Readiness for blended learning: Understanding attitude of university students. International Journal of Cyber Society and Education, 6(2): 79-100.Available at: https://doi.org/10.7903/ijcse.1086.

Tomlinson, B. and C. Whittaker, 2013. Blended learning English language teaching: Course design and implementation. London: British Council.

Vaughan, N., 2007. Perspectives on blended learning in higher education. International Journal on E-learning, 6(1): 81-94.

Wang, Y., X. Han and J. Yang, 2015. Revisiting the blended learning literature: Using a complex adaptive systems framework. Journal of Educational Technology \& Society, 18(2): 380-393.

Winarso, W., 2016. Assessing the readiness of student learning activity and learning outcome. Journal Pencerahan, 10(2): 81-94. 